\title{
PREVENTIVE ROLES OF BIOACTIVE NATURAL COMPOUNDS IN OXIDATIVE AND NITROSATIVE STRESS MEDIATED PATHOPHYSIOLOGY OF DIABETES MELLITUS
}

\author{
SATYAPRAKASH BERAIYA ${ }^{1}$, PIR MOHAMMAD ISHFAQ ${ }^{1}$, ZAVED AHMAD ${ }^{1}$, SWATI TRIPATHI ${ }^{2}$, \\ SIDDHARTHA KUMAR MISHRA ${ }^{1 *}$
}

${ }^{1}$ Cancer Biology Laboratory, School of Biological Sciences (Zoology), Dr. Harisingh Gour Central University, Sagar, Madhya Pradesh, India. ${ }^{2}$ Amity Institute of Microbial Technology, Amity University, Noida, Uttar Pradesh, India. Email: siddharthakm@yahoo.com

Received: 17 July 2019, Revised and Accepted: 14 August 2019

\begin{abstract}
Oxidative stress has emerged as one of the targets in several medical conditions and in several types of clinical researches. Growing evidences from research on diverse diseases show that oxidative stress is conjoined with the pathogenesis of diabetes and its complications. This review has examined the role of oxidative stress in the pathogenesis of insulin resistance and beta-cell dysfunction. A vast variety of medicinal plants and products have been utilized for the prevention of diabetes and its related complications. Natural products such as phenolic acids and flavonoids construct one of the most ubiquitous groups of plant phenolics. At present, the effect of dietary phenolics is of extreme concern due to their antioxidant, free radical scavenging, and as quenchers of singlet oxygen formation. Reactive oxygen species (ROS) as well as reactive nitrogen species play either harmful or beneficial roles in biological systems depending on pathophysiological conditions. This review extends on the fundamental aspect of ROS in biological processes and diseases and how natural bioactive compounds of fruits and vegetables regulate their health improving properties. Flavonoids and phenolics acids are the most important groups of secondary metabolites and bioactive compounds in plants. Diverse phytochemical agents have become the backbone in pharmacotherapy of diabetes by virtue of their antioxidant properties along with their other pharmacological actions. Consequently, accession to obstruction the generation of reactive free radicals or abduct the reactive free radical may yield direct and casual approach for the medication of diabetes and its complications.
\end{abstract}

Keywords: Natural products, Diabetes mellitus, Free radicals, Oxidative stress, Prevention.

(C) 2019 The Authors. Published by Innovare Academic Sciences Pvt Ltd. This is an open access article under the CC BY license (http://creativecommons. org/licenses/by/4. 0/) DOI: http://dx.doi.org/10.22159/ajpcr.2019.v12i10.34886

\section{INTRODUCTION}

Diabetes mellitus is a universal health complication that causes a leading risk of vascular diseases, decline in the quality of life, and enhanced mortality rate. Diabetes mellitus patients undergo several alterations in metabolism, which exert detrimental effects in many organs in the body, particularly the cardiovascular system [1]. Basically, it is a syndrome defined by hyperglycemia, polydipsia, and polyuria and complications to the kidney, eyes, nerves, and it also conjoins with an enlarged prevalence of cardiovascular diseases [2]. The contemporary knowledge of free radicals and reactive oxygen species (ROS) in biological systems is bringing forth a revolution in the medical field. ROS plays an important role in living systems through their beneficial and detrimental effects [3]. The diabetes control and complications trial revealed that tight regulation of blood glucose is capable of diminishing clinical complications notably, but even optimal control over blood glucose could not prohibit diabetic complications. This suggests that there must be some alternative treatment procedures [4]. Several studies have manifested that hyperglycemia-induced generation of free radicals causes oxidative stress which imparts toward the development and progression of diabetes and related complications (Fig. 1). It became clear that mitigation of oxidative stress through antioxidants therapy maybe an impressive policy for decreasing diabetic complications [5]. Plants are potential sources of natural bioactive compounds such as secondary metabolites. Most of the secondary metabolites of herbs and spices are commercially important and find use in a number of pharmaceutical compounds with diverse properties including anticancer effects [6]. A large cluster of plant-derived various bioactive compounds have exhibited activity persistent with their possible role in the pathophysiology of diabetes [7]. Among these are polysaccharides, alkaloids, galactomannan gun, peptidoglycans, glycosides, hypoglycans, carbohydrates, steroids, glycopeptides, guanidine, terpenoids, inorganic ions, and amino acids. In fact, the disclosure of extensively used hypoglycemic drug metformin emerges from the conventional access to using Galega officinalis [8]. Nowadays, there is a developing concern in the applicability of medicinal plants for the medication and execution of type 2 diabetes. These plants have been inked in mythical medicine from prehistoric time by virtue of their antioxidant and antidiabetic activities. However, they are easily available and cost-effective having lower side effects in comparison to synthetically designed antidiabetic remedies [9]. Recently available therapies for diabetes comprises insulin and numerous antidiabetics orally agents such as biguanides, sulfonylureas, and glinides. However, most of them have a genuine detrimental effect consequently, the investigation for a more potent and secure hypoglycemic remedy is one of the essential areas of research [10]. This review involved an extensive focus on the oxidative stress-mediated pathophysiological conditions of diabetes and the use of a vas variety of medicinal plants and products for the prevention of diabetes and its related complications.

\section{OXIDATIVE STRESS AND ANTIOXIDANTS}

Diabetes mellitus is defined by high levels of glucose and ROS overproduction is a characteristic feature (Fig. 2). High glucose can commence the generation of superoxide and hydrogen peroxide, precursors of reactive free radicals, which causes to stimulate the weakening of antioxidant systems, damage biomolecules, raise lipid peroxidation, and promote the insulin resistance in diabetes [11]. Numerous biochemical mechanisms have become known to reveal the detrimental issue of hyperglycemia, including protein kinase $\mathrm{C}$ (PKC), mitogen-activated protein kinase (MAPK), polyol pathway, advanced glycation end (AGE) products, and oxidative stress [12]. Hyperglycemia influences conversion of glucose to sorbitol which leads to a collateral decline of nicotinamide adenine dinucleotide phosphate 
and glutathione, which, in turn, is liable for the failure of antioxidant equivalents that are more prone to increase intracellular oxidative stress [13]. $\alpha$-tocopherol, a phenolic compound, and ascorbic acid occurred in fruits, grains, vegetables, and pulses retain the potentiality to reduce oxidative damage affiliated with many diseases, including cardiovascular diseases, cancer, cataracts, diabetes, atherosclerosis, arthritis, immune deficiency diseases, and aging [14]. Increased oxidative stress is considered to show a significant aspect in the etiology and pathophysiology of the chronic complications linked with diabetes $[15,16]$.

Streptozotocin (STZ) toxin has been widely used to produce diabetic animal models. In STZ treated rats, it has been implied that increased generation of ROS, hyperglycemia, and auto-oxidation of glycated protein are associated with pancreatic $\beta$ cell damage $[17,18]$. Vitamin $C$ acts as an essential antioxidant in human, capable of steal oxygenderived free radicals. Vitamin $\mathrm{C}$ is structurally related to glucose and can displace it in various chemical reactions, and this is efficient in a prohibition of non-enzymatic glycosylation of proteins [19]. Oxidative stress has been implied broadly as a potential mechanism for diabetic nephropathy because oxidative stress stimulates the production of AGE as well as activation of PKC-MAPK pathways [20,21]. Basically, an action of oxidative stress has been marked by the existence of lipid peroxidation products and 8-hydroxydeoxyguanosine in the kidney of STZ-induced diabetic rats $[22,23]$. In relation to the defense system to oxidative stress, antioxidant enzymes such as $\mathrm{Cu} / \mathrm{Zn}$-superoxide dismutase (Cu/Zn-SOD) and catalase were found to be elevated in kidneys of STZ-induced diabetic rats [24]. A plentiful dose of antioxidants either from the diet or from another route might help to prohibit or delay the presence of oxidative drift. Cobalt only or with a union of ascorbate has been determined to decline lipid peroxidation in STZ-induced diabetic rats in different organs such as the kidney, liver, heart, and aorta $[25,26]$.

Ruination in the oxidant/antioxidant equilibrium generates oxidative stress, which causes molecular and cellular tissue damage in a wide range of human diseases [27]. There are many endogenous enzyme systems that keep safe the cell and tissue from oxidative stress, for example, SOD, catalase, and glutathione peroxidase (GSH-Px). Despite the fact there is disputation about the antioxidant status in diabetic complications, various studies described decline levels of SOD and GSH-Px in both clinical and experimental diabetes, reveal an impaired defense system for scavenging of free radical. Autoxidation of glucose is the sources of ROS in Yu [28].

Oxidative stress plays an essential role in diabetic complications; it is assumed to be linked with increased lipid peroxidation. Hyperglycemia and dyslipidemia in diabetes mellitus promote increased lipid peroxidation and peroxyl radical formation which are important mechanisms in the genesis of microangiopathy [29]. Other factors that are increased in diabetics are free fatty acids and leptin which are also associated with the increased of ROS. Protein AGE products also increases with age, which is also increased in diabetics. The aggregation of AGE causes to increase in the microvascular lesions, present in diabetic retinopathy and is also liable for cardiovascular complications, commonly present in diabetic patients [30].

\section{SOURCE OF OXIDATIVE STRESS IN DIABETES}

Free radicals are the elementary part of any biochemical action and exhibit a crucial role in our metabolism and aerobic life. The greater detrimental effect of free radicals is on DNA. Alteration in DNA has been recommended to be liable in the processes of diabetes mellitus. Every living cell has the strength to struggle against free radicals besides its enzymatic defense systems such as SOD, catalase, glutathione reductase, and GSH-Px [31]. Evaluation of oxidative stress markers such as plasma and urinary F2-isoprostane as well as plasma and tissue levels of nitrotyrosine and $\bullet \mathrm{O}_{2}$ provides direct evidence of the oxidative stress in diabetes and their complications [32]. Sources of oxidative stress in diabetes mainly include enzymatic, nonenzymatic, and mitochondrial pathways. Enzymatic sources of enhanced production of reactive species in diabetes include NOS, NAD(P)H oxidase, and xanthine oxidase [33]. Nonenzymatic sources of oxidative stress derived from the oxidation of glucose. Hyperglycemia can directly cause enhanced ROS production. Glucose can go through autoxidation and form $\bullet \mathrm{OH}$ radicles [34], and also reacts with proteins in a nonenzymatic manner leading to the formation of AGEs. ROS is generated at multiple steps during this process. In hyperglycemia, there is increased metabolism of glucose through the polyol (sorbitol) pathway, which also results in enhanced production of $\bullet \mathrm{O}_{2}$. The ROS are also formed in the mitochondrial respiratory chain as a non-enzymatic way by the oxidative phosphorylation process, from electron carriers NADH and FADH2, transferred electrons through the four complexes in the inner mitochondrial membrane to the oxygen, originate adenosine triphosphate in the process [35]. Nonenzymatic antioxidants comprise Vitamins A, C, and E, glutathione, $\alpha$-lipoic acid, carotenoids, and trace elements such as copper, zinc, and selenium, coenzyme Q10, and cofactors such as folic acid, uric acid, albumin, and Vitamins B1, B2, B6, and B12. Variations in the antioxidant defense system in diabetic complications have latterly been examined [36].

\section{MEDICINAL PLANTS AS BIOACTIVE NATURAL COMPOUNDS AS ANTIDIABETICS}

In India, ethnobotanical and ethnopharmacological therapies have been used a vast variety of medicinal plants and products in the medication of diabetes mellitus since the time of Sushruta and Charaka ( $6^{\text {th }}$ century BC) [37]. Plants have always been an excellent source of drugs, and most of the currently accessible drugs have been borrowed directly or indirectly from them. The ethnobotanical data reports that there are about 800 plants which may retain the potential of antidiabetic [38]. Numerous medicinal plants have been used as a dietary supplement from a long time and in the medication of various diseases without the proper doctrine of their function. Although phytotherapy continues to be used in many countries, rare medicinal plants have gotten scientific and medical scrutiny. Moreover, a large number of medicinal plants retain some extent of toxicity. It is also proclaimed that one-third of medicinal plants used in the remedy of diabetic complications is examined to be toxic $[39,40]$. Since a long time, several plants are examined to be a wealthy source of potent antidiabetic drugs and these herbal extracts are examined to be lacking any side effects. It has been predicted that more than 400 plants species and their secondary metabolites such as glycosides, alkaloids, terpenoids, flavonoids, carotenoids, tannins, and polyphenolic derivatives are being used for the execution of diabetes mellitus and their complications [41]. Dried ripe fruit of Terminalia chebula Retz (Combretaceae) is broadly used in Ayurveda and is generally found throughout India, Sri Lanka, and Burma. It is commonly known as black myroblans in English and has conventionally used in the medication of asthma, vomiting, hiccough, diarrhea, bleeding piles, sore throat, gout and bladder, and heart diseases. A herbal production "TRIPHALA" composed of T. chebula is a precise common medicine for the cure of chronic complications along with diabetes, also reported having free radical scavenging and strong antioxidant activities [42]. Tamarindus indica has been used as source of dietary modifications for reducing diabetes associated cardiovascular disease risk factors. Its extract showed antioxidant action by lowering oxidative stress and lipid-lowering mechanisms. The extract caused improvement in the efficiency of the antioxidant enzymes activity, especially SOD, catalase, and GSH-Px activities [43]. An ethanolic extract of Commiphora mukul gum resin was assessed for its antidiabetic effects on the brain of STZinduced diabetes in rats [44]. Diabetic rats showed remarkable decline in the levels of total lipids and other lipid molecules, triglycerides, acetylcholine, and proteins level. The extract, when treated at a concentration of $200 \mathrm{mg} / \mathrm{kg}$ in STZ-diabetic rats dramatically, reversed the degenerative changes through a mechanism involving antioxidant effects [44]. This represents a significant example of preventing diabetes using a natural plant product.

At present, there has been an expanded interest globally to find antioxidant compounds that are pharmacologically potent and have low 


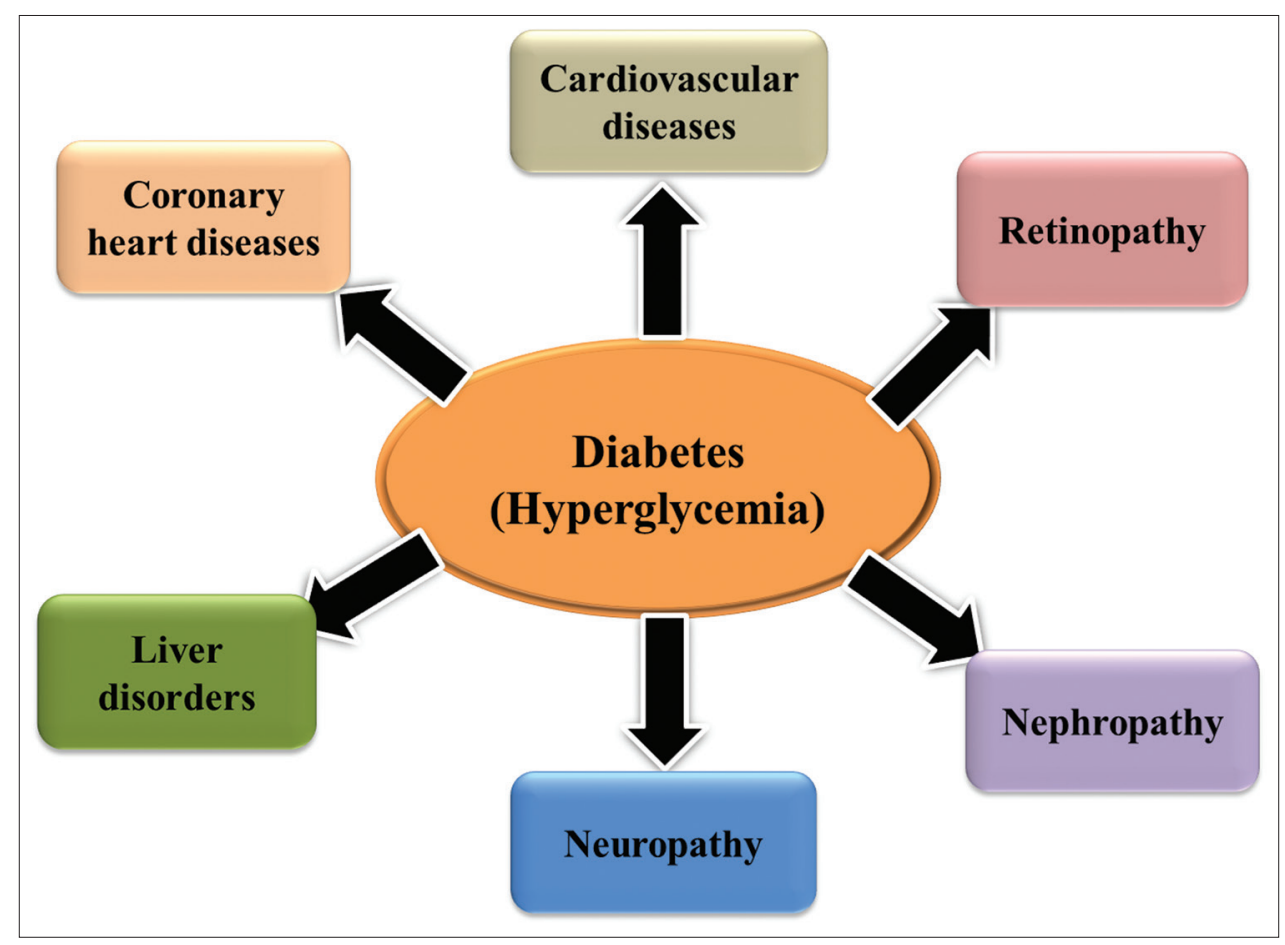

Fig. 1: Complications associated with diabetes. Diabetes may be classified as a syndrome containing conditions of hyperglycemia, polydipsia, and polyuria, as well as, it affects functions of several vital organs leading to complications of kidney, eyes, nervous system, and cardiovascular system

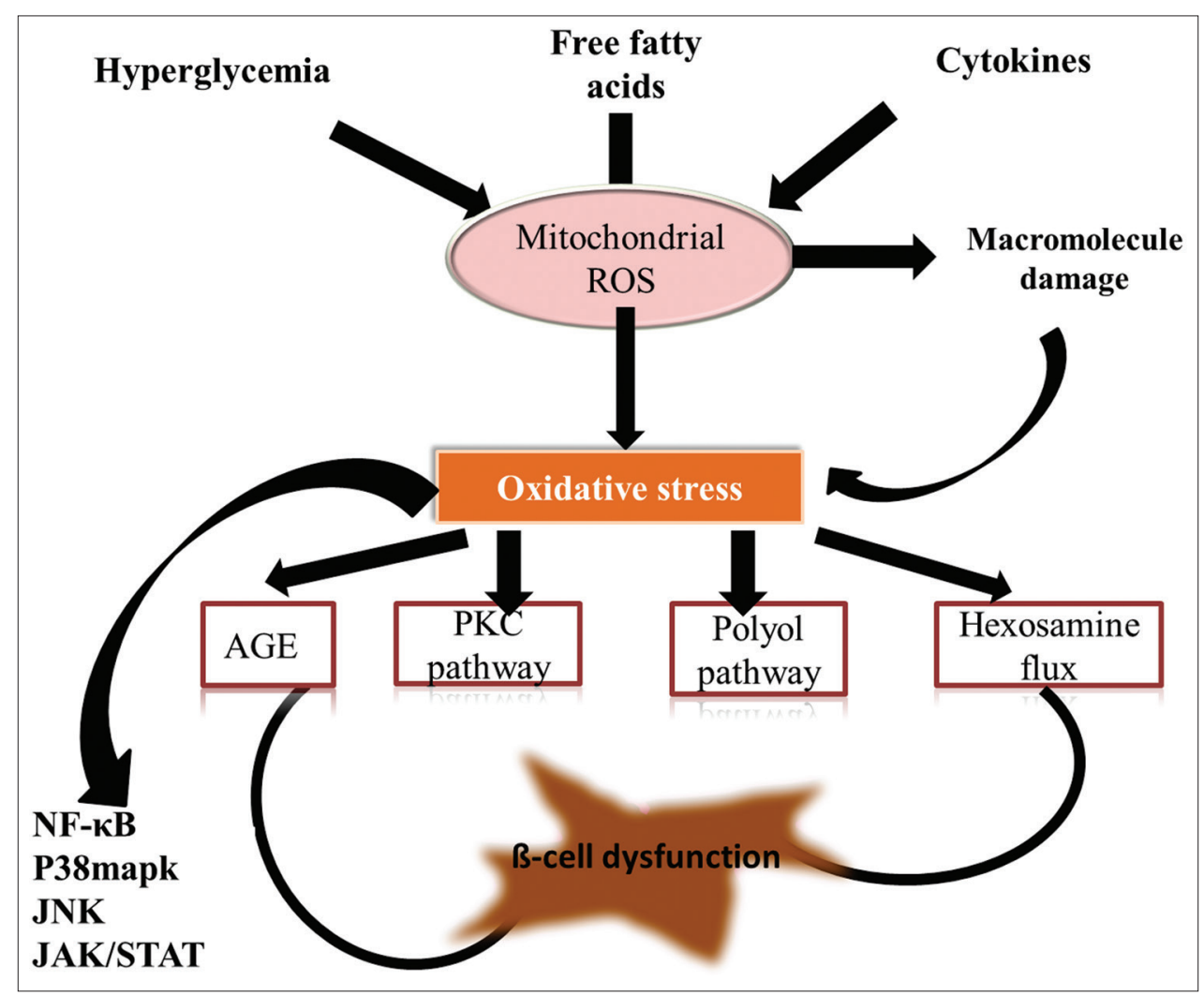

Fig. 2: Cumulative effect and mechanism of ROS generation through hyperglycemia, free fatty acids, and cytokines. Excess generation of mitochondrial ROS activates stress-sensitive pathways including polyol, advanced glycation end products, PKC, and hexosamine flux. Detailed mechanisms are discussed in the text of the present study. NF-кB: Nuclear factor-kappa B; JNK: c-Jun N-terminal kinases; JAK: Janus kinase; STAT: Signal transducer and activator of transcription 
Table 1: Comparative list of natural plant products in diabetic remedies

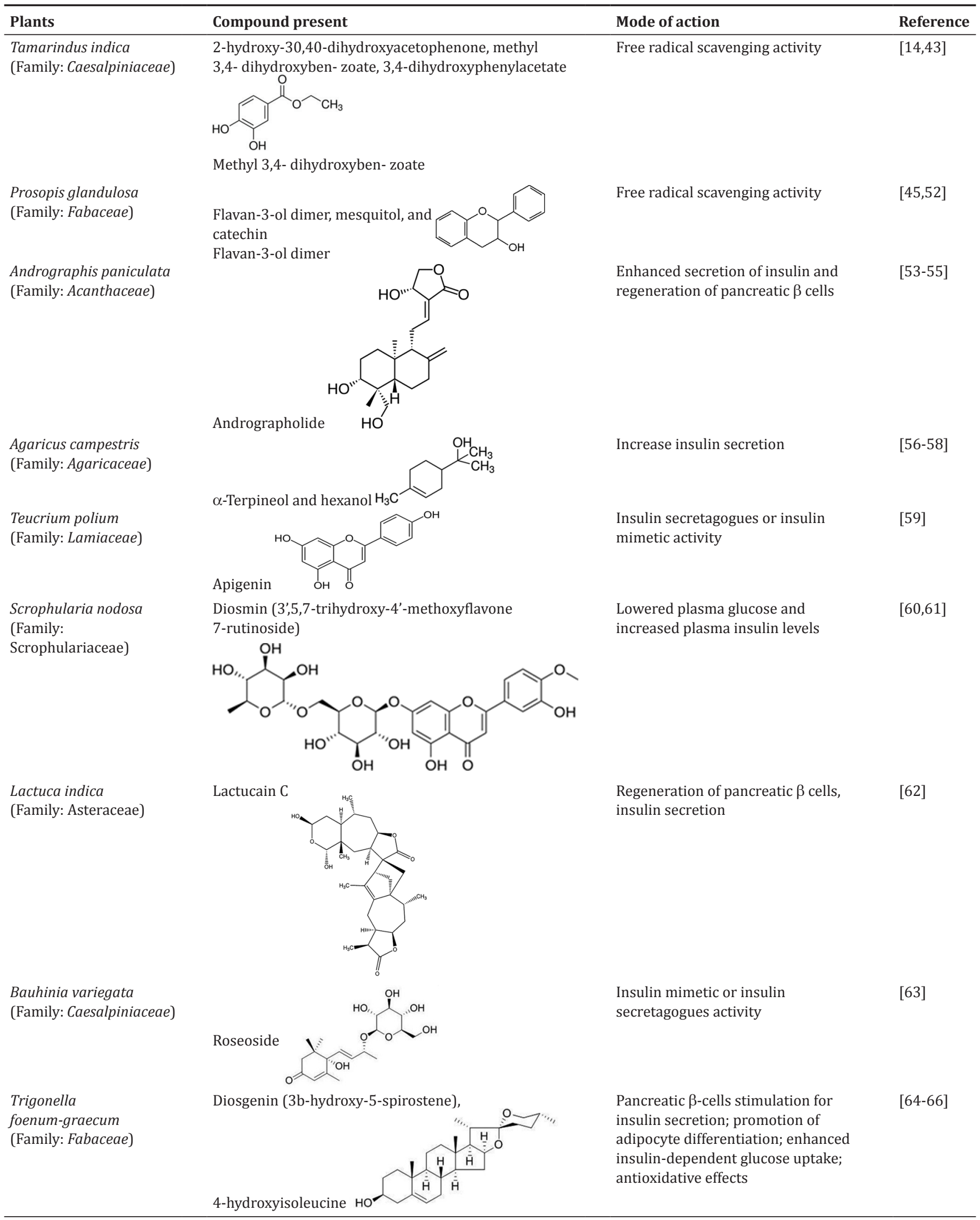


Table 1: (Continued)

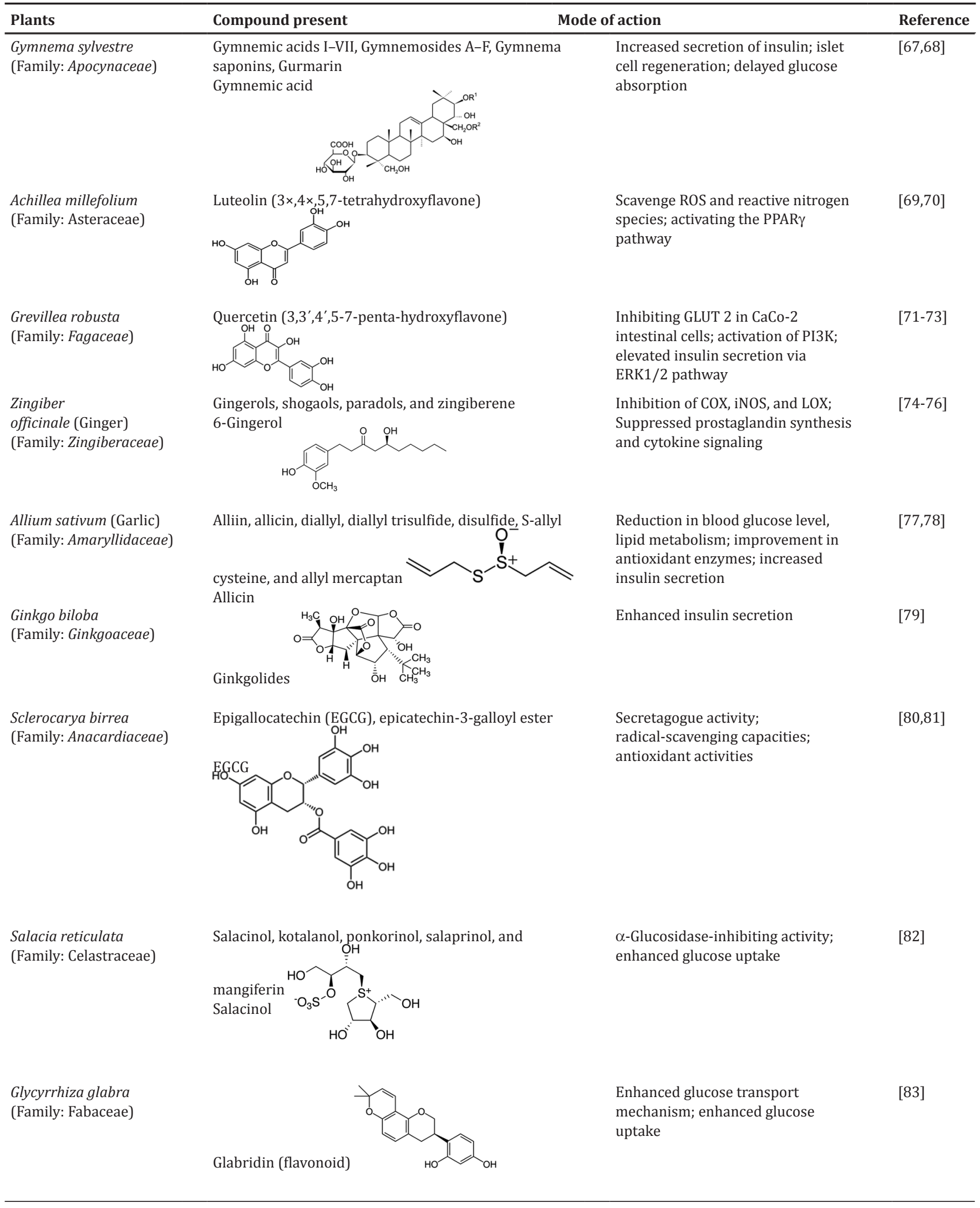


Table 1: (Continued)

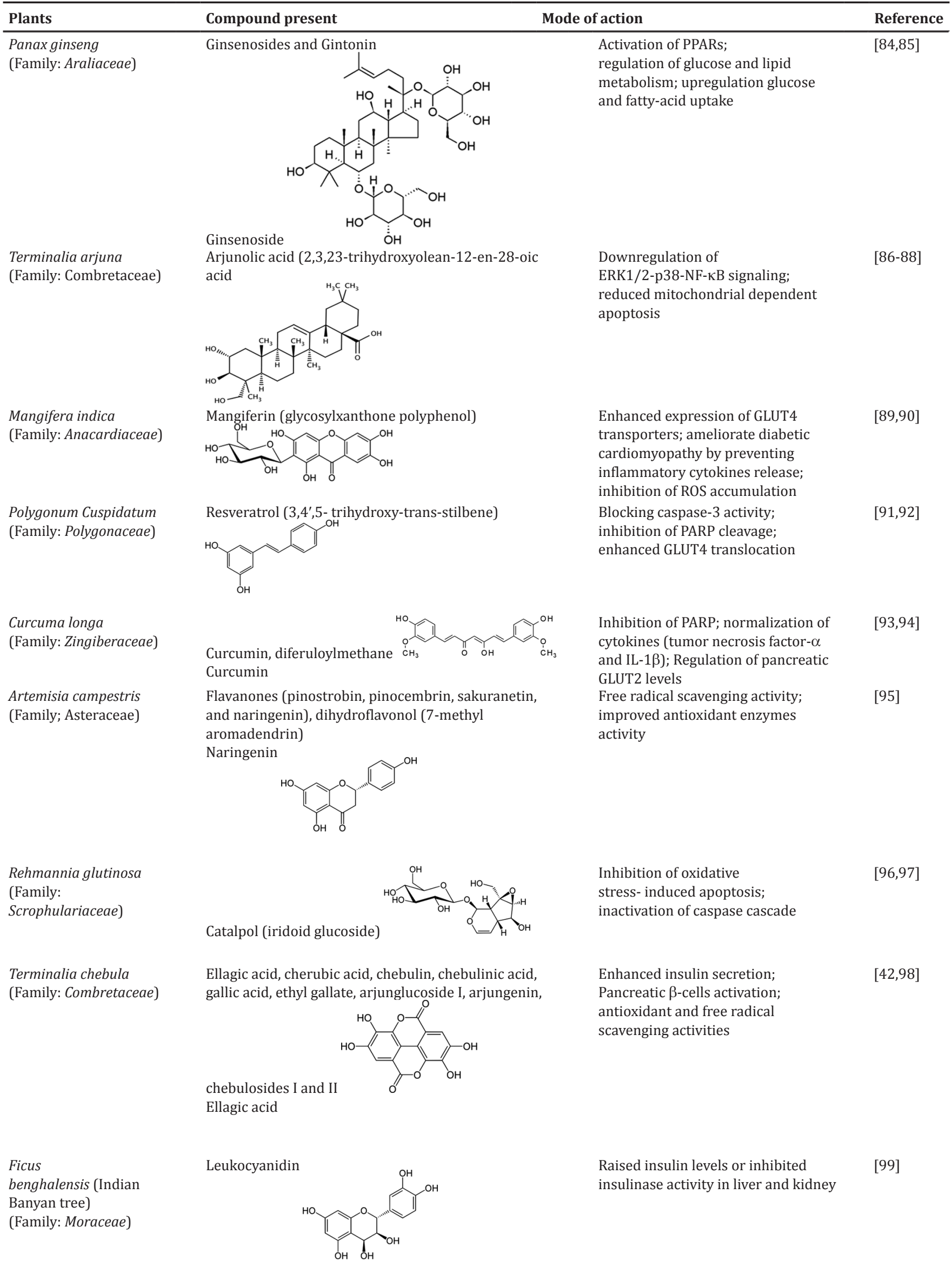


Table 1: (Continued)

\begin{tabular}{|c|c|c|c|}
\hline Plants & Compound present & f action & Reference \\
\hline $\begin{array}{l}\text { Clerodendrum volubile } \\
\text { (Family: Labiatae) }\end{array}$ & $\begin{array}{l}\text { Kaempferol and 4',-methoxy-5,7-dihydroxy } \\
\text { isoflavone (biochanin) } \\
\text { Kaempferol }\end{array}$ & $\begin{array}{l}\text { Increased serum insulin and } \\
\text { pancreatic } \mathrm{Ca}^{2+} \text { levels; improved } \\
\beta \text {-cell distribution and function; } \\
\text { improved glucose tolerance }\end{array}$ & {$[9,100]$} \\
\hline $\begin{array}{l}\text { Momordica charantia } \\
\text { (Bitter melon) } \\
\text { (Family: Cucurbitaceae) }\end{array}$ & $\begin{array}{l}\text { Momordicine II and 3-hydroxycucurbita-5, } \\
\text { 24-dien-19-al-7, 23-di-0- } \beta \text {-glucopyranoside }\end{array}$ & $\begin{array}{l}\text { Activation of AMP protein kinase } \\
\text { activity }\end{array}$ & {$[101]$} \\
\hline $\begin{array}{l}\text { Hemidesmus indicus } \\
\text { (Family: Asclepidaceae) }\end{array}$ & $\begin{array}{l}\text { Amyrin, sitosterol, hemidesmin, 2-Hydroxy 4-methoxy } \\
\text { benzoic acid } \\
\text { Amyrin }\end{array}$ & $\begin{array}{l}\text { Antioxidant, anti-inflammatory, } \\
\text { immunomodulatory activities; } \\
\text { protection from oxidative } \\
\text { stress-induced DNA strand breaks }\end{array}$ & [49] \\
\hline
\end{tabular}

side effects for use in antidiabetic therapy. Even though various types of synthetically prepared oral hypoglycemic agents and insulin are there for the medication of diabetes mellitus, synthetic agents can cause toxicity and genuine side effects over the body. Consequently, investigation for secure and impressive agents has extended to be an essential area of active research. Thus, there is a developing concern to find natural antidiabetic remedies to cure diabetes. In available literature plant species having hypoglycemic activity is more than 400 . Despite, seeking for new antidiabetic remedies from natural plants is still an attractive aspect of research. Most of the plants contain glycosides, alkaloids, terpenoids, flavonoids, and carotenoids that are generally involved as having antidiabetic effects [45]. Polyphenolic compounds may influence in glycemia by distinct mechanisms, along with the prohibition of absorption of glucose in the gut or restraint of its uptake by peripheral tissue. Polyphenols trigger secretion of tumor necrosis factor- $\alpha$ and interferon- $\gamma$, thus restraining status of inflammation and evolvement of microvascular diabetic complications [46]. Polysaccharides obtained from higher plants are almost nontoxic and do not cause significant side effects, which is a major problem associated with synthetic compounds. Polysaccharides are the main active compounds present in Momordica charantia L. which shows antioxidant and immunoenhancing properties and could protect against cerebral ischemia/reperfusion injury [47]. Taking of flavonoids rich compounds has been noted to reduce the incidence of chronic diseases such as diabetes and cardiovascular complications. Naringenin (4,5,7-trihydroxy flavanone), the active form of naringin, occurred in Citrus paradisi (grapefruit) has shown potential biomedical applications in diabetes remedy [48]. Hemidesmus indicus (Asclepiadaceae) locally known as anantamul (Indian sarsaparilla) is widely dispersed all over India. H. indicus root extract is commonly used as anti-inflammatory, antioxidant, immunomodulatory, and antidote in the Indian system of medicine. H. Indicus root extract has been disclosed to secure from radiation-induced DNA strand breakage. The hypoglycemic response of $H$. indicus root extract in the STZinduced diabetic model has earlier been described [49]. Quercetin is the most extensively used and widely radiated flavonols in human dietary with proclaimed antidiabetic and anti-inflammatory activity. Numerous mechanisms of its action enclose prohibition of intestinal glucose absorption by the interference of GLUT2 transporter, a decline of lipid peroxidation, and suppression of $\alpha$-glucosidase and $\alpha$-amylase.
With the accelerated incidence of diabetic complications, a demand of active phytochemicals with antidiabetic activity emerge [50]. A piece of growing evidence proved that flavonoids derived from medicinal plants and vegetables have a valuable response on diabetes by ameliorating antioxidant status, glycemic control, and lipid profile.

Rutin (Vitamin P) is a bioflavonoid that is present in several plants notably Ruta graveolens, Sophora japonica, and Fagopyrum esculentum. A diverse biological response comprising, antioxidant, neuroprotective, anti-inflammatory, hepatoprotective, and nephroprotective activities has been disclosed for this flavonoid [51]. World ethnobotanical data about medicinal plants reports that about 800 plants are used in the restraint of diabetes mellitus, out of them only 400 have been experimentally verified, but the complete knowledge of their mechanisms of action is available only for about 100 plants. The vital effective bioactive components of these plants include glycosides, glycopeptides polysaccharides, alkaloids, and peptidoglycans these molecules exert its effects on several metabolic pathways and their cascade, which directly or indirectly influence the level of glucose in the human body.

On the basis of their mode of action, herbal medicines for diabetes can be classified into four categories:

- Drugs acting like insulin e.g., $M$. charantia (bitter melon)

- Drugs acting on insulin-secreting $\beta$-cells e.g., Allium cepa (onion)

- Drugs acting by modifying glucose utilization e.g., Zingiber officinale (ginger)

- Drugs acting by miscellaneous mechanisms, for example, Panax ginseng (ginseng)

The observations from Table 1 indicate that several natural products have been utilized for preventing diabetes by different mechanisms. Among them, polyphenols are an abundant heterogeneous group of phytochemicals present in plant-based foods, such as tea, coffee, cocoa, wine, legumes, cereal grains, fruit, and berries. The studies carried out in animal models, and a limited number of humans provide strong evidence that polyphenols rich foods and beverages have attenuated postprandial glycemic responses and fasting hyperglycemia, and enhanced instance insulin secretion and insulin sensitivity. The probable mechanisms of 
action consist of restraint of carbohydrate digestion and absorption of glucose in the intestine, incitement of insulin secretion from the pancreatic beta cells, stimulation of insulin receptors and uptake of glucose in the insulin-sensitive tissues, and intonation of intracellular signaling cascade and ultimately influence gene expression [102]. Polyphenols are of many types, i.e., flavonoids, stilbenes lignans, and phenolic acids. Flavonoids can be further separated into flavonols, flavonols, flavones, isoflavones, flavanones, and anthocyanins [103]. Flavonoids are secondary metabolites of fungi and plants carrying a 15-carbon skeleton contains two phenyl rings and a heterocyclic ring, which are previously known as the pigments providing the colors of leaves, fruit, and flowers [104]. Flavonols are the most pervasive flavonoids in foods, and the major representatives are kaempferol and quercetin generally found at relatively low concentrations of $15-30 \mathrm{mg} / \mathrm{kg}$ fresh wt. The healthy sources are onions (up to $1.2 \mathrm{~g} / \mathrm{kg}$ fresh wt), leeks curly, kale, broccoli, and blueberries [105]. Kaempferol, a dietary flavonol abundantly found in Ginkgo biloba L., grapefruit, broccoli, kale, tea, broccoli, and many other edible plants species. Kaempferol has anti-oxidant and anti-inflammatory effects in several diseases including diabetes [106]. Kaempferol was found to have a possessive effect on pancreatic $\beta$-cell. Its protective action is an accomplice with enhanced cAMP signaling, inhibition of cellular [107]. Kaempferol restrains NF$\kappa \mathrm{B}$ signaling cascade activation, thus suppresses hepatic inflammation, and assign in the amelioration of insulin signaling defect in diabetes. Orally administration of kaempferol decline fasting blood glucose level and enhanced insulin resistance [108]. The anthocyanins are flavonoids abundant in dark-colored fruit, such as berries which are of nutritional interest as they are also one of the principal sources of the widely consumed dietary polyphenols in vegetables and fruit. Various studies have been going on to explore the impact of the utilization of purified anthocyanins on the development and amelioration of type 2 diabetes mellitus [109].

\section{CONCLUSIONS}

The inflection of signal transducing pathways by naturally occurring various phytochemicals has newly been continued to annotate the molecular basis of diabetes. Several agents which are the backbone of pharmacotherapy for diabetes have antioxidant properties along with other pharmacological actions. Therefore, approach to block the production of reactive free radicals or steal the reactive free radical may produce targeted and casual access for the cure of diabetes and its complications. This review has enclosed many medicinal plants that could be used in the cure of diabetes. However, some of the other plant's species that have not yet been fully explored may have therapeutic implications in diabetes. The elaborating of new antidiabetic moieties from bioactive compounds is necessary to find more impressive and less toxic antidiabetic drugs. Therefore, further extensive studies on the potential of different plants with isolated bioactive compounds showing antidiabetic activity should go through additional in vitro and in vivo animal testing followed by toxicity and clinical tests. This may provide a promising compound to be optimized and suitable for application in the production of new antidiabetic compounds. Although orally administration of the antioxidants containing extract of antidiabetic plants in the STZ-induced diabetic mice shows the beneficiary results in the hyperglycemic condition. Metabolites and phytochemicals from various plants are reported to exhibit strong antioxidant properties in terms of both enzymatic and non-enzymatic activities. Recent researches have also revealed that a number of plants families, such as Leguminosae, Lamiaceae, Liliaceae, Cucurbitaceae, Asteraceae, Moraceae, Rosaceae, and Araliaceae, have shown antidiabetic and hypoglycaemic activities attributed to their unique metabolites such as flavonoids, triterpenoids, limonoids, and polysaccharides. As the incidence of diabetic and their complications raises, a demand for efficacious bioactive phytochemicals with antidiabetic activity increases and growing evidence regarding the antidiabetic activity of many plants or their constituents prepare a strong area of efficient and secure remedies for prohibition and management of diabetes. This review provides a direct link between the oxido-nitrosative stress and the use of phytochemicals present in medicinal plants in the pathophysiology and management aspect of diabetic complications.

\section{ACKNOWLEDGMENTS}

M.P. Council of Science and Technology, Bhopal, India, is acknowledged for providing funding in the form of the research project (No. R and D(BS.)/17-18/09/2018).

\section{AUTHORS' CONTRIBUTIONS}

S.P. searched literature and wrote the manuscript; P.M.I. and Z.A. analyzed contents and assisted in manuscript preparation; S.T. and S.K.M. overall supervised the research work, edited and finalized the manuscript.

\section{CONFLICTS OF INTEREST}

We declare that we have no conflicts of interest.

\section{REFERENCES}

1. Factor SM, Minase T, Sonnenblick EH. Clinical and morphological features of human hypertensive-diabetic cardiomyopathy. Am Heart J 1980;99:446-58.

2. Pickup JC. Inflammation and activated innate immunity in the pathogenesis of type 2 diabetes. Diabetes Care 2004;27:813-23.

3. Jakus V. The role of free radicals, oxidative stress and antioxidant systems in diabetic vascular disease. Bratisl Lek Listy 2000;101:54151 .

4. Diabetes Control and Complications Trial Research Group, Nathan DM, Genuth S, Lachin J, Cleary P, Crofford O, et al. The effect of intensive treatment of diabetes on the development and progression of long-term complications in insulin-dependent diabetes mellitus. N Engl J Med 1993;329:977-86.

5. Johansen JS, Harris AK, Rychly DJ, Ergul A. Oxidative stress and the use of antioxidants in diabetes: Linking basic science to clinical practice. Cardiovasc Diabetol 2005;4:5.

6. Zeenat A, Archana M, Siddhartha Kumar M. Ethnopharmacological review of natural products in cancer prevention and therapy. Asian J Pharm Clin Res 2018;11:32-44

7. Muhammad A, Mahadeva US, Ahmad Bashir A, Khamsah Suryati M, Thant Z. Some natural products and their secondary metabolites attributed towards diabetic cure: A review. Int J Pharm Pharm Sci 2015;7:22-8.

8. Grover JK, Yadav S, Vats V. Medicinal plants of India with antidiabetic potential. J Ethnopharmacol 2002;81:81-100.

9. Erukainure OL, Hafizur RM, Kabir N, Choudhary MI, Atolani O, Banerjee P, et al. Suppressive effects of Clerodendrum volubile $\mathrm{P}$ beauv. [Labiatae] methanolic extract and its fractions on type 2 diabetes and its complications. Front Pharmacol 2018;9:8.

10. Saxena A, Vikram NK. Role of selected Indian plants in management of type 2 diabetes: A review. J Altern Complement Med 2004;10:36978

11. Afanas'ev I. Signaling of reactive oxygen and nitrogen species in diabetes mellitus. Oxid Med Cell Longev 2010;3:361-73.

12. Koya D, Hayashi K, Kitada M, Kashiwagi A, Kikkawa R, Haneda M. Effects of antioxidants in diabetes-induced oxidative stress in the glomeruli of diabetic rats. J Am Soc Nephrol 2003;14:S250-3.

13. Karunakaran U, Park KG. A systematic review of oxidative stress and safety of antioxidants in diabetes: Focus on islets and their defense. Diabetes Metab J 2013;37:106-12.

14. Siddhuraju P. Antioxidant activity of polyphenolic compounds extracted from defatted raw and dry heated Tamarindus indica seed coat. LWT Food Sci Tech 2007;40:982-90

15. Baynes JW. Role of oxidative stress in development of complications in diabetes. Diabetes 1991;40:405-12.

16. Vincent AM, Brownlee M, Russell JW. Oxidative stress and programmed cell death in diabetic neuropathy. Ann N Y Acad Sci 2002;959:368-83.

17. Desco MC, Asensi M, Márquez R, Martínez-Valls J, Vento M, Pallardó FV, et al. Xanthine oxidase is involved in free radical production in type 1 diabetes: Protection by allopurinol. Diabetes 2002;51:1118-24.

18. Hunt JV, Dean RT, Wolff SP. Hydroxyl radical production and autoxidative glycosylation. Glucose autoxidation as the cause of protein damage in the experimental glycation model of diabetes mellitus and ageing. Biochem J 1988;256:205-12.

19. Afkhami-Ardekani M, Shojaoddiny-Ardekani A. Effect of Vitamin C on blood glucose, serum lipids \& serum insulin in type 2 diabetes 
patients. Indian J Med Res 2007;126:471-4

20. Brownlee M. Biochemistry and molecular cell biology of diabetic complications. Nature 2001;414:813-20.

21. Ha H, Kim KH. Pathogenesis of diabetic nephropathy: The role of oxidative stress and protein kinase C. Diabetes Res Clin Pract 1999; 45:147-51.

22. Ha H, Kim C, Son Y, Chung MH, Kim KH. DNA damage in the kidneys of diabetic rats exhibiting microalbuminuria. Free Radic Biol Med 1994;16:271-4.

23. Horie K, Miyata T, Maeda K, Miyata S, Sugiyama S, Sakai H, et al. Immunohistochemical colocalization of glycoxidation products and lipid peroxidation products in diabetic renal glomerular lesions. Implication for glycoxidative stress in the pathogenesis of diabetic nephropathy. J Clin Invest 1997;100:2995-3004.

24. Sechi LA, Ceriello A, Griffin CA, Catena C, Amstad P, Schambelan $\mathrm{M}$, et al. Renal antioxidant enzyme mRNA levels are increased in rats with experimental diabetes mellitus. Diabetologia 1997;40:23-9.

25. Yildirim O, Büyükbingöl Z. Effect of cobalt on the oxidative status in heart and aorta of streptozotocin-induced diabetic rats. Cell Biochem Funct 2003;21:27-33

26. Yildirim Ö. The effect of Vitamin $\mathrm{C}$ and cobalt supplementation on antioxidant status in healthy and diabetic rats. Afr J Biotech 2009;8:5053-8

27. Peuchant E, Delmas-Beauvieux MC, Couchouron A, Dubourg L, Thomas MJ, Perromat A, et al. Short-term insulin therapy and normoglycemia. Effects on erythrocyte lipid peroxidation in NIDDM patients. Diabetes Care 1997;20:202-7.

28. Yu BP. Cellular defenses against damage from reactive oxygen species. Physiol Rev 1994;74:139-62.

29. Samuel TV, Murthy JD, Dattatreya, Babu PS, Johncy SS. Impaired antioxidant defence mechanism in diabetic retinopathy. J Clin Diagnos Res 2010;4:3430-6.

30. Rahman K. Studies on free radicals, antioxidants, and co-factors. Clin Interv Aging 2007;2:219-36.

31. Chandran R, George BP, Abrahamse H, Parimelazhagan T. Therapeutic effects of Syzygium mundagam bark methanol extract on type-2 diabetic complications in rats. Biomed Pharmacother 2017;95:167-74.

32. Oberg BP, McMenamin E, Lucas FL, McMonagle E, Morrow $\mathrm{J}$, Ikizler TA, et al. Increased prevalence of oxidant stress and inflammation in patients with moderate to severe chronic kidney disease. Kidney Int 2004;65:1009-16.

33. Guzik TJ, Mussa S, Gastaldi D, Sadowski J, Ratnatunga C, Pillai R, et al. Mechanisms of increased vascular superoxide production in human diabetes mellitus: Role of $\mathrm{NAD}(\mathrm{P}) \mathrm{H}$ oxidase and endothelial nitric oxide synthase. Circulation 2002;105:1656-62.

34. Turko IV, Marcondes S, Murad F. Diabetes-associated nitration of tyrosine and inactivation of succinyl-coA:3-oxoacid coA-transferase. Am J Physiol Heart Circ Physiol 2001;281:H2289-94.

35. Green K, Brand MD, Murphy MP. Prevention of mitochondrial oxidative damage as a therapeutic strategy in diabetes. Diabetes 2004;53 Suppl 1:S110-8.

36. Vega-López S, Devaraj S, Jialal I. Oxidative stress and antioxidant supplementation in the management of diabetic cardiovascular disease. J Investig Med 2004;52:24-32.

37. Grover JK, Vats V, Rathi SS. Anti-hyperglycemic effect of Eugenia jambolana and Tinospora cordifolia in experimental diabetes and their effects on key metabolic enzymes involved in carbohydrate metabolism. J Ethnopharmacol 2000;73:461-70.

38. Alarcon-Aguilara FJ, Roman-Ramos R, Perez-Gutierrez S, AguilarContreras A, Contreras-Weber CC, Flores-Saenz JL. Study of the antihyperglycemic effect of plants used as antidiabetics. J Ethnopharmacol 1998;61:101-10.

39. Bnouham M, Ziyyat A, Mekhfi H, Tahri A, Legssyer A. Medicinal plants with potential antidiabetic activity - A review of ten years of herbal medicine research (1990-2000). Int J Diab Metabol 2006;14:1.

40. Marles R. Plants as sources of antidiabetic agents. Econ Med Plant Res 1994;6:149-87.

41. Bailey CJ, Day C. Traditional plant medicines as treatments for diabetes. Diabetes Care 1989;12:553-64.

42. Nalamolu KR, Nammi S. Antidiabetic and renoprotective effects of the chloroform extract of Terminalia chebula retz. seeds in streptozotocininduced diabetic rats. BMC Complement Altern Med 2006;6:17.

43. Martinello F, Soares SM, Franco JJ, Santos AC, Sugohara A, Garcia SB, et al. Hypolipemic and antioxidant activities from Tamarindus indica L. pulp fruit extract in hypercholesterolemic hamsters. Food Chem Toxicol 2006;44:810-8.

44. Sudhakara G, Ramesh B, Mallaiah P, Manjunatha B, Desireddy S.
Protective effect of commiphora mukul gum resin on brain in streptozotocin-induced diabetic rats. Int $\mathrm{J}$ Pharm Pharm Sci 2015;7:406- 11

45. Patel DK, Prasad SK, Kumar R, Hemalatha S. An overview on antidiabetic medicinal plants having insulin mimetic property. Asian Pac J Trop Biomed 2012;2:320-30.

46. Badescu M, Badulescu O, Badescu L, Ciocoiu M. Effects of Sambucus nigra and Aronia melanocarpa extracts on immune system disorders within diabetes mellitus. Pharm Biol 2015;53:533-9.

47. Xu X, Shan B, Liao CH, Xie JH, Wen PW, Shi JY. Anti-diabetic properties of Momordica charantia L. polysaccharide in alloxaninduced diabetic mice. Int J Biol Macromol 2015;81:538-43.

48. Li JM, Che CT, Lau CB, Leung PS, Cheng CH. Inhibition of intestinal and renal $\mathrm{Na}+$-glucose cotransporter by naringenin. Int $\mathrm{J}$ Biochem Cell Biol 2006;38:985-95.

49. Gayathri M, Kannabiran K. 2-hydroxy 4-methoxy benzoic acid isolated from roots of Hemidesmus indicus ameliorates liver, kidney and pancreas injury due to streptozotocin-induced diabetes in rats. Indian J Exp Biol 2010;48:159-64.

50. Ota A, Ulrih NP. An overview of herbal products and secondary metabolites used for management of type two diabetes. Front Pharmacol 2017;8:436.

51. Ghorbani A. Mechanisms of antidiabetic effects of flavonoid rutin. Biomed Pharmacother 2017;96:305-12.

52. George C, Lochner A, Huisamen B. The efficacy of Prosopis glandulosa as antidiabetic treatment in rat models of diabetes and insulin resistance. J Ethnopharmacol 2011;137:298-304.

53. Mishra SK, Sangwan NS, Sangwan RS. Andrographis paniculata (Kalmegh): A review. Pharmacog Rev 2007;1:283-98.

54. Yu BC, Hung CR, Chen WC, Cheng JT. Antihyperglycemic effect of andrographolide in streptozotocin-induced diabetic rats. Planta Med 2003;69:1075-9.

55. Mishra SK, Tripathi S, Shukla A, Oh SH, Kim HM. Andrographolide and analogues in cancer prevention. Front Biosci (Elite Ed) 2015;7:25566.

56. Gray AM, Flatt PR. Insulin-releasing and insulin-like activity of Agaricus campestris (mushroom). J Endocrinol 1998;157:259-66.

57. Pinent M, Blay M, Bladé MC, Salvadó MJ, Arola L, Ardévol A. Grape seed-derived procyanidins have an antihyperglycemic effect in streptozotocin-induced diabetic rats and insulinomimetic activity in insulin-sensitive cell lines. Endocrinology 2004;145:4985-90.

58. Rankin JW, Andreae MC, Oliver Chen CY, O'Keefe SF. Effect of raisin consumption on oxidative stress and inflammation in obesity. Diabetes Obes Metab 2008;10:1086-96.

59. Mirghazanfari SM, Keshavarz M, Nabavizadeh F, Soltani N, Kamalinejad M. The effect of "Teucrium polium L." extracts on insulin release from in situ isolated perfused rat pancreas in a newly modified isolation method: The role of $\mathrm{Ca} 2+$ and $\mathrm{K}+$ channels. Iran Biomed $\mathrm{J}$ 2010;14:178-85.

60. Pari L, Srinivasan S. Antihyperglycemic effect of diosmin on hepatic key enzymes of carbohydrate metabolism in streptozotocin-nicotinamideinduced diabetic rats. Biomed Pharmacother 2010;64:477-81.

61. Silambarasan T, Raja B. Diosmin, a bioflavonoid reverses alterations in blood pressure, nitric oxide, lipid peroxides and antioxidant status in DOCA-salt induced hypertensive rats. Eur J Pharmacol 2012;679:81-

62. Hou CC, Lin SJ, Cheng JT, Hsu FL. Antidiabetic dimeric guianolides and a lignan glycoside from Lactuca indica. J Nat Prod 2003;66:625-9.

63. Frankish N, de Sousa Menezes F, Mills C, Sheridan H. Enhancement of insulin release from the beta-cell line INS-1 by an ethanolic extract of Bauhinia variegata and its major constituent roseoside. Planta Med 2010;76:995-7.

64. Kalailingam P, Kannaian B, Tamilmani E, Kaliaperumal R. Efficacy of natural diosgenin on cardiovascular risk, insulin secretion, and beta cells in streptozotocin (STZ)-induced diabetic rats. Phytomedicine 2014;21:1154-61

65. Uemura T, Hirai S, Mizoguchi N, Goto T, Lee JY, Taketani K, et al. Diosgenin present in fenugreek improves glucose metabolism by promoting adipocyte differentiation and inhibiting inflammation in adipose tissues. Mol Nutr Food Res 2010;54:1596-608.

66. Son IS, Kim JH, Sohn HY, Son KH, Kim JS, Kwon CS. Antioxidative and hypolipidemic effects of diosgenin, a steroidal saponin of yam (Dioscorea spp.), on high-cholesterol fed rats. Biosci Biotechnol Biochem 2007:71:3063-71.

67. Tiwari P, Mishra BN, Sangwan NS. Phytochemical and pharmacological properties of Gymnema sylvestre: An important medicinal plant. Biomed Res Int 2014;2014:830285. 
68. Kumar V, Bhandari U, Tripathi CD, Khanna G. Protective effect of Gymnema sylvestre ethanol extract on high fat diet-induced obese diabetic wistar rats. Indian J Pharm Sci 2014;76:315-22.

69. Horváthová K, Chalupa I, Sebová L, Tóthová D, Vachálková A. Protective effect of quercetin and luteolin in human melanoma HMB2 cells. Mutat Res 2005;565:105-12.

70. Ding L, Jin D, Chen X. Luteolin enhances insulin sensitivity via activation of PPAR $\gamma$ transcriptional activity in adipocytes. J Nutr Biochem 2010;21:941-7.

71. Kwon O, Eck P, Chen S, Corpe CP, Lee JH, Kruhlak M, et al. Inhibition of the intestinal glucose transporter GLUT2 by flavonoids. FASEB J 2007;21:366-77.

72. Stewart LK, Wang Z, Ribnicky D, Soileau JL, Cefalu WT, Gettys TW. Failure of dietary quercetin to alter the temporal progression of insulin resistance among tissues of $\mathrm{C} 57 \mathrm{BL} / 6 \mathrm{~J}$ mice during the development of diet-induced obesity. Diabetologia 2009;52:514-23.

73. Longuet C, Broca C, Costes S, Hani EH, Bataille D, Dalle S. Extracellularly regulated kinases $1 / 2$ (p44/42 mitogen-activated protein kinases) phosphorylate synapsin I and regulate insulin secretion in the MIN6 beta-cell line and islets of langerhans. Endocrinology 2005; $146: 643-54$

74. Jolad SD, Lantz RC, Solyom AM, Chen GJ, Bates RB, Timmermann BN. Fresh organically grown ginger (Zingiber officinale): Composition and effects on LPS-induced PGE2 production. Phytochemistry 2004; $65: 1937-54$

75. Arablou T, Aryaeian N, Valizadeh M, Sharifi F, Hosseini A, Djalali M. The effect of ginger consumption on glycemic status, lipid profile and some inflammatory markers in patients with type 2 diabetes mellitus. Int J Food Sci Nutr 2014;65:515-20.

76. de Lima RM, Dos Reis AC, de Menezes AP, Santos JV, Filho $\mathrm{JW}$, Ferreira JR, et al. Protective and therapeutic potential of ginger (Zingiber officinale) extract and [6]-gingerol in cancer: A comprehensive review. Phytother Res 2018;32:1885-907.

77. Wang J, Zhang X, Lan H, Wang W. Effect of garlic supplement in the management of type 2 diabetes mellitus (T2DM): A meta-analysis of randomized controlled trials. Food Nutr Res 2017;61:1377571.

78. Liu CT, Wong PL, Lii CK, Hse H, Sheen LY. Antidiabetic effect of garlic oil but not diallyl disulfide in rats with streptozotocin-induced diabetes. Food Chem Toxicol 2006:44:1377-84

79. Pinto Mda S, Kwon YI, Apostolidis E, Lajolo FM, Genovese MI, Shetty K. Potential of Ginkgo biloba L. leaves in the management of hyperglycemia and hypertension using in vitro models. Bioresour Technol 2009;100:6599-609.

80. Dimo T, Rakotonirina SV, Tan PV, Azay J, Dongo E, Kamtchouing P, et al. Effect of Sclerocarya birrea (Anacardiaceae) stem bark methylene chloride/methanol extract on streptozotocin-diabetic rats. J Ethnopharmacol 2007;110:434-8.

81. Dièye AM, Sarr A, Diop SN, Ndiaye M, Sy GY, Diarra M, et al. Medicinal plants and the treatment of diabetes in Senegal: Survey with patients. Fundam Clin Pharmacol 2008;22:211-6.

82. Yoshikawa M, Nishida N, Shimoda H, Takada M, Kawahara Y, Matsuda H. Polyphenol constituents from Salacia species: Quantitative analysis of mangiferin with alpha-glucosidase and aldose reductase inhibitory activities. Yakugaku Zasshi 2001;121:371-8.

83. Bai L, Li X, He L, Zheng Y, Lu H, Li J, et al. Antidiabetic potential of flavonoids from traditional Chinese medicine: A review. Am J Chin Med 2019;47:933-57.

84. Auwerx J, Schoonjans K, Fruchart JC, Staels B. Transcriptional control of triglyceride metabolism: Fibrates and fatty acids change the expression of the LPL and apo C-III genes by activating the nuclear receptor PPAR. Atherosclerosis 1996;124 Suppl: S29-37.

85. Gui QF, Xu ZR, Xu KY, Yang YM. The efficacy of ginseng-related therapies in type 2 diabetes mellitus: An updated systematic review and meta-analysis. Medicine (Baltimore) 2016;95:e2584

86. Zhang Q, ElSohly HN, Li XC, Walker LA. A new triterpene from Leandra chaetodon. Planta Med 2003;69:582-4.

87. Manna P, Sinha M, Sil PC. Protective role of arjunolic acid in response to streptozotocin-induced type-I diabetes via the mitochondrial dependent and independent pathways. Toxicology 2009;257:53-63.
88. Raghavan B, Kumari SK. Effect of terminalia arjuna stem bark on antioxidant status in liver and kidney of alloxan diabetic rats. Indian J Physiol Pharmacol 2006;50:133-42.

89. Girón MD, Sevillano N, Salto R, Haidour A, Manzano M, Jiménez $\mathrm{ML}$, et al. Salacia oblonga extract increases glucose transporter 4-mediated glucose uptake in L6 rat myotubes: Role of mangiferin. Clin Nutr 2009;28:565-74.

90. Hou J, Zheng D, Fung G, Deng H, Chen L, Liang J, et al. Mangiferin suppressed advanced glycation end products (AGEs) through NF- $\kappa$ B deactivation and displayed anti-inflammatory effects in streptozotocin and high fat diet-diabetic cardiomyopathy rats. Can J Physiol Pharmacol 2016;94:332-40.

91. $\mathrm{Ku} \mathrm{CR}$, Lee HJ, Kim SK, Lee EY, Lee MK, Lee EJ. Resveratrol prevents streptozotocin-induced diabetes by inhibiting the apoptosis of pancreatic $\beta$-cell and the cleavage of poly (ADP-ribose) polymerase. Endocr J 2012;59:103-9.

92. Deng JY, Hsieh PS, Huang JP, Lu LS, Hung LM. Activation of estrogen receptor is crucial for resveratrol-stimulating muscular glucose uptake via both insulin-dependent and -independent pathways. Diabetes 2008:57:1814-23

93. Meghana K, Sanjeev G, Ramesh B. Curcumin prevents streptozotocininduced islet damage by scavenging free radicals: A prophylactic and protective role. Eur J Pharmacol 2007;577:183-91.

94. Kanitkar M, Gokhale K, Galande S, Bhonde RR. Novel role of curcumin in the prevention of cytokine-induced islet death in vitro and diabetogenesis in vivo. Br J Pharmacol 2008;155:702-13.

95. Hong JH, Lee IS. Effects of Artemisia capillaris ethyl acetate fraction on oxidative stress and antioxidant enzyme in high-fat diet induced obese mice. Chem Biol Interact 2009;179:88-93

96. Jiang B, Liu JH, Bao YM, An LJ. Catalpol inhibits apoptosis in hydrogen peroxide-induced PC12 cells by preventing cytochrome c release and inactivating of caspase cascade. Toxicon 2004;43:53-9.

97. Hu L, Sun Y, Hu J. Catalpol inhibits apoptosis in hydrogen peroxideinduced endothelium by activating the PI3K/Akt signaling pathway and modulating expression of bcl-2 and bax. Eur J Pharmacol 2010;628:155- 63

98. Saha S, Verma RJ. Antioxidant activity of polyphenolic extract of Terminalia chebula retzius fruits. J Univ Sci 2016;10:805-12.

99. Achrekar S, Kaklij GS, Pote MS, Kelkar SM. Hypoglycemic activity of Eugenia jambolana and Ficus bengalensis: Mechanism of action. In Vivo 1991;5:143-7.

100. Adefegha SA, Oboh G. Antioxidant and inhibitory properties of Clerodendrum volubile leaf extracts on key enzymes relevant to noninsulin dependent diabetes mellitus and hypertension. J Taibah Univ Sci 2016;10:521-33.

101. Leung L, Birtwhistle R, Kotecha J, Hannah S, Cuthbertson S. Antidiabetic and hypoglycaemic effects of Momordica charantia (bitter melon): A mini review. Br J Nutr 2009;102:1703-8.

102. Hanhineva K, Törrönen R, Bondia-Pons I, Pekkinen J, Kolehmainen M, Mykkänen $\mathrm{H}$, et al. Impact of dietary polyphenols on carbohydrate metabolism. Int J Mol Sci 2010;11:1365-402.

103. Manach C, Scalbert A, Morand C, Rémésy C, Jiménez L. Polyphenols: Food sources and bioavailability. Am J Clin Nutr 2004;79:727-47.

104. Kawser Hossain M, Abdal Dayem A, Han J, Yin Y, Kim K, Kumar Saha S, et al. Molecular mechanisms of the anti-obesity and antidiabetic properties of flavonoids. Int J Mol Sci 2016;17:569.

105. Manach C, Donovan JL. Pharmacokinetics and metabolism of dietary flavonoids in humans. Free Radic Res 2004;38:771-85

106. Calderón-Montaño JM, Burgos-Morón E, Pérez-Guerrero C, López-Lázaro M. A review on the dietary flavonoid kaempferol. Mini Rev Med Chem 2011;11:298-344.

107. Zhang Y, Liu D. Flavonol kaempferol improves chronic hyperglycemiaimpaired pancreatic beta-cell viability and insulin secretory function. Eur J Pharmacol 2011;670:325-32.

108. Vinayagam R, Xu B. Antidiabetic properties of dietary flavonoids: A cellular mechanism review. Nutr Metab (Lond) 2015;12:60.

109. Guo H, Ling W. The update of anthocyanins on obesity and type 2 diabetes: Experimental evidence and clinical perspectives. Rev Endocr Metab Disord 2015;16:1-13. 